\title{
The Effect of Nutritional Status, Physical Fitness Level and Motivation Towards Learning Outcomes of PJOK of Students at Class X SMA Pertiwi 1 Padang
}

\author{
Muhammad Azizan Shah
}

\author{
Sport Science Faculty, Universitas Negeri Padang, Prof. Dr.Hamka, Padang, Indonesia \\ *Corresponding author. Email: m.azizan.shah.17@gmail.com
}

\begin{abstract}
The problem in this research has not been the maximum of students learning outcomes of PJOK seen from a large number of students who have grades below the minimum completeness criteria. This type of research is quantitative correlation with a causal associative approach. The purpose of the study was to determine the direct influence of nutritional status (X1), physical fitness (X2), and learning motivation (X3) on learning outcomes of PJOK (Y). The research population was a student in high school Pertiwi 1 amount 45 people. The sampling technique is simple random sampling. The data was collected by using a Likert scale questionnaire for learning motivation. The results of the data analysis showed that the path coefficient was normal, significant and linear. (1) There was a significant direct effect on nutritional status of PJOK toward learning outcomes. (2) There was a significant direct effect of physical fitness of PJOK toward learning outcomes. (3) There is a significant direct effect of learning motivation toward PJOK learning outcomes. (4) There was a direct influence of nutritional status motivation toward learning. (5) There was a direct influence of Physical Fitness toward learning motivation.
\end{abstract}

\section{Keywords: Learning Outcomes of PJOK, Nutritional Status, Physical Fitness, learning motivation}

\section{INTRODUCTION}

Several factors may determine learning outcomes, namely from himself (internal) and from outside himself (external). Factors that influence learning outcomes: (1) Internal factors (originating from within), namely health, intelligence, talent, interests, motivation, ways of learning. Then (2) external factors (coming from outside) are: family, school, community, environment "[1].

Broad health factors are certainly very closely related to a person's nutritional status, nutritional status can describe how good a person's nutrition. A good nutritional status of a person is seen from the balance of nutritional intake with energy needs, vitamins, minerals and others. With a balanced nutritional intake and consumption of nutritious foods and drinks, the body has enough nutrients needed in the process of maintaining, repairing and growing tissue in the body.

Sources of calories contained in food can be processed into energy that can sustain daily activities. In the daily body requires energy that moves, energy obtained from nutrients in food and drinks that have been consumed by the body. The daily activities of students who are solid as a learning process carried out at school and after school outside, of course, require a nutrient-rich food intake.

Furthermore, the internal factors of learning outcomes related to psychology such as intelligence, talent, motivation, interests and attitudes of students, make psychological factors play an important role in the learning of students' outcomes, the psychological state of psychology students can determine student learning outcomes. overall. Basic or innate genetic ability (talent) in learning something with a short span of time, but the results are satisfying, talent is the basis of the potential possessed by students, but talent is not possible between one and the other. While other internal psychological factors as motivation have an impact on learning outcomes.

Motivation in the nature of every human being, where motivation is a psychological condition that encourages in taking an action, but the size of motivation can affect an action that must be done to achieve the goal. External factors that can improve their learning outcomes as stated earlier, external factors are one of the most important elements where there is family, environment such as friends and neighbors, and school and infrastructure provided by the school. Learners' needs for positive encouragement from external factors allow students to achieve learning outcomes in physical exercise and health education.

Based on observations and observations during the learning process of physical education in class X of SMA Pertiwi 1 paddock in the academic year 2017/2018, researchers see the effectiveness of low learning materials in physical education and health sports of some students, especially female students in school. Seen some students who are lazy in doing physical education teaching and 
health training, this can be caused by the things that can interfere with the effectiveness of learning.

The low nutritional status clearly impacts the quality of human resources. Therefore, nutritional status is a factor that provides a considerable influence on one's achievement. Nutrition is one of the important factors in contributing to the quality of human resources [2]

Laziness arising in ourselves from some students, this may be caused by factors of poor health. Seen some students have problems with the nutritional status of these students as nutrition and malnutrition. In this case, students will likely experience difficulties in learning physical and sports physical education material. In other cases, the state of nutritional status can affect student performance in carrying out the learning process because it is difficult or slow to realize motor skills, low movement skills, lazy during the learning process, fatigue, decreased level of student interest, low student motivation during the learning process.

Good nutritional intake plays an important role in achieving optimal body growth. Optimal body growth includes brain growth which greatly determines one's intelligence. The final impact of consumption of good and balanced nutrition is an increase in the quality of human resources [3].

In addition, researchers also saw some students who have problems in terms of fitness, as evidenced by a student who easily feels exhausted when doing learning or afterwards, the possible causes are one of the low levels of the level of some cardiovascular students, the need for oxygen is not met by well. Low fitness services students will certainly interfere with the learning process that has an impact on students' motivation, interests and attitudes that are not good. If this situation continues it will affect its value.

Other factors seen from problems experienced by students such as heat conditions caused by the heat of the sun that causes them to experience excessive dehydration, unscheduled eating, discrimination of others, invitations to peers who are not good, high laziness to move, lack of interest and low student motivation for student learning in the learning process will end with an assessment of unsatisfactory learning outcomes.

But among all subjects seen most students enjoy physical exercise and health education (PJOK) lessons. but the reality that occurs in the field in terms of the results of the assessment of learning subjects PJOK students are a number of class $\mathrm{X}$ students of Padang Pertiwi in the academic year 2017/2018 below the minimum completeness criteria value (KKM) and are required to undergo female remedial especially in female students. Carry out an assessment of the function by educators intended as a monitoring tool and evaluation process of learning progress and improvement of learning outcomes produced by participating students on an ongoing basis and to assess the achievement of graduation competency standards.

Furthermore, the assessment of learning outcomes by educators is carried out in the form of tests and is used as a determinant of graduation, if students do not reach students who have not yet been completed in the subjects requested by PJOK to apply remedies as a graduation condition for students who do not reach the KKM "learners who have not yet reaching the KKM education unit must follow remedial learning "[4].

Evidenced by the results of observations made by previous researchers, it can be seen from some of the first class X Pertiwi high schools in the first semester of the academic year 2017/2018, the results of the improvement test before students have not reached the KKM have been determined by the school. It was identified that 25 out of 89 students could not yet be equipped with indicators on PJOK subjects, inversely proportional to the $82 \%$ percentages at the minimum level of PJOK learning mastery standards stated in the category above the Minimum Completeness Criteria (KKM).

From the data obtained that $22 \%$ of students have low grades below the KKM of 89 female students. Evidenced by the results of recapitulation from previous observations that have been made, in which the assessment of physical education and sports learning outcomes difference difference ranges from numbers or 5 , for example $(65,70$, $75,80,85$, and 90). Then realized in the assessment of learning outcomes, as follows; 3 students with a value of 65,8 female students with a score of 70 , and then 16 students with a value of 75 . This causes students to be encouraged to do remedial on PJOK subjects.

The goal to be achieved through this research is to uncover. (1) the direct influence of nutritional status on learning outcomes of PJOK grade X SMA 1 Padang Pertiwi in the Academic Year 2017/2018. (2) The direct effect of physical fitness tests on PJOK grade $\mathrm{X}$ learning outcomes of SMA 1 Padang Pertiwi in the Academic Year 2017/2018. (3) the direct effect of motivation on the learning outcomes of PJOK class X SMA 1 Padang Pertiwi in the Academic Year 2017/2018. (4) the direct influence of nutritional status on learning motivation of class X students of SMA 1 Padang Pertiwi for the Academic Year 2017/2018. (5) The magnitude of the direct influence of the level of motivation on jamani fitness class X SMA 1 Padang Pertiwi Academic Year $2017 / 2018$

\section{METHODOLOGY}

This type of research is quantitative research with an associative causal correlation approach. The purpose of this study was to determine the direct influence of nutritional status, level of physical fitness, and motivation on learning outcomes of physical education and sports in class X SMA 1 Padang Pertiwi in the academic year $2017 / 2018$. This research is classified in quantitative research that uses simple regression data analysis techniques and multiple regression, then proceed with path analysis (path analysis).

This research was conducted on May 11, 2018. This research took place at SMA Pertiwi 1 Padang for the implementation of data collection on learning outcomes, the next course of research conducted in the baseline of learning motivation to build Nikken UNP workforce, thus 
assessing students' physical fitness levels. in the area of Nikken UNP's workforce development and track on the football field of the Nikken Padang State University.

In this study, the population was higher class X SMA 1 Padang Pertiwi academic year 2017/2018, Consists of 7 classes, namely; 1) X IBB, 2) X Mathematics 1, 3) X Mathematics 2, 4) X IIS 1, 5) X IIS 2,6) X IIS 3, 7) X IIS 4.

From the table above, it can be understood that in this study, the population of class X students of SMA 1 Padang Pertiwi in the academic year 2017/2018 amounted to 89 people.

The population of this study was 89 students in class $\mathrm{X}$ Padang 1, which consisted of 89 students. Population The number of samples taken in the study by Issac and Michael is a sample of $50 \%$ of the total population [5]. $50 \%$ of the total population of 89 was 44.7 then rounded 45 . Then the sample that participated in this study amounted to 45 people.

Research Instruments

Learning Outcomes are classroom voting on newly acquired abilities of students through a learning process that contains elements of movement in the form of systematic physical activity that has been carried out with reference to the cognitive, psychomotor and affective domain assessments. instruments in PJOK learning outcomes, researchers use classroom-based assessment instruments found from physical education and sports health teachers related to assessments in the enforcement documents of assessment of learning outcomes of administration assessments, assessment instruments, management assessments by schools and teachers must be realized in the form of student score recap.

Nutritional status instrument is a clear form of body condition or health condition resulting from nutrient intake (intake) and the amount needed by the body (required) within the scope of nutritional intake needs that vary in each individual depending on age, sex, body and other activities. The instrument used to measure student nutrition is a height gauge in meters (Microtoice) nutritional status measured by body mass index (BMI) values with the formula BMI = weight $/ \mathrm{TB} 2(\mathrm{~kg} / \mathrm{m} 2)$

Healthy Indonesia Physical Freshness Test (TKJI) is a field test tool for children aged 6-19 years, divided into four age groups, namely 6-9 years; 10-12 years; 13-15 years; and 16-19 years. Each age group and gender is a series of tests, each of which consists of a five-point test for each age group based on gender.

One of the motivational tests for learning non-test instruments used is a questionnaire. Non-test instruments are used to collect data on student learning motivation, questionnaires / scales arranged according to the Likert scale method, alternative student responses to statements of each instrument item consisting of five categories of choices: Always (SL), Often (S), Now and sometimes sometimes (KK), Rare (JR), Never (TP). Instrument tests are given before treatment. Samples are asked to fill in the

Individual tests carried out $\mathrm{X} 3$ to $\mathrm{Y}$ found that the path coefficient of spyx 3 results $=0.295$ with $t=2.274$ and $t$ answers based on alternative answers provided below the question.

The instrument used to measure the motivation of this study was a Likert scale questionnaire model with five alternative answers consisting of strongly agree (SS), agree (S), doubt (RR), disagree (TS), and strongly disagree (STS). Each alternative answer has a different weight, according to the type of statement, whether positive or negative.

Data analysis technique

The data analysis technique used is descriptive and inferential to find a description of the spread characteristics of the scores of each variable studied. Descriptive analysis is used in data presentation, center size, and size of distribution. Presentation of data uses a frequency distribution list and a histogram. The central size includes average (average), medium average (median), and repeat value (mode). The size of the spread includes variance and standard deviation (Standard Deviation). Whereas inferential analysis / causal analysis is used to test the analysis requirements and hypotheses using path analysis modeling (Part Analysis).

\section{RESULTS}

Based on the results of the normality test calculation variable, it was found that the L0 value obtained was smaller than the significance level of Lt $\alpha=0.05$. Thus, we can conclude that all groups of data in this study were drawn from normally distributed populations so that they could be used and continue to test the research hypotheses.

Next to the data X1 to X3 the significance value of the $\mathrm{F}>\mathrm{F}$ table and linearity of the $\mathrm{F}<\mathrm{F}$ table. It is clear that there is a linear and significant relationship between nutritional status or variables (X1) on PJOK learning outcomes (Y), with $\mathrm{X} 2$ data the significance value is $\mathrm{F}>\mathrm{F}$ table and linearity $\mathrm{F}<\mathrm{F}$ table. It is clear that there is a linear relationship between Physical Fitness (X2) variables and PJOK learning outcomes, it can be understood that all variables have a significant linear relationship or influence so that they can be used and continue to test the research hypothesis.

Direct influence of nutritional status (X1) on learning outcomes of PJOK (Y). Individual tests conducted X1 to Y found that the $\mathrm{sp} 1 \mathrm{x} 1$ path coefficient results $=0.305$ with $\mathrm{t}$ $=2.096$ and $t$ table $(1-0.05)(44-1)=1.67$ (at $\alpha=0.05$ ). Because $\mathrm{t}=2,096>\mathrm{t}$ table $=1.67$, Ho is rejected, meaning a significant path coefficient. Thus Nutrition Status (X1) has a direct and significant impact on PJOK (Y) learning outcomes. The Direct Effect of Physical Fitness (X2) on Learning Outcomes of PJOK (Y). Individual tests conducted $\mathrm{X} 2$ to $\mathrm{Y}$ found that the path coefficient of the spyx 2 results $=0.373$ with $t=2.620$ and table $(1-0.05)$ $(44-1)=1.67$ (at $\alpha=0.05)$. Because $\mathrm{t}=2,620>\mathrm{t}$ table $=$ 1.67 , Ho is rejected, meaning a significant path coefficient. Thus Physical Fitness (X2) has a direct and significant impact on PJOK learning outcomes (Y). Direct Effect of Motivation (X3) on Learning Outcomes of PJOK (Y). tables $(1-0.05)(44-1)=1.67$ (at $\alpha=0.05)$. Because $\mathrm{t}=$ 2,274 $>$ table $=1.67$, Ho is rejected, meaning a significant 
path coefficient. Thus learning motivation (X3) has a tcomes (Y).

Direct influence of nutritional status (X1) Motivation Study (X3). Individual tests conducted X1 to X3 were obtained from the path coefficient value pyx31 $=0.493$ with $\mathrm{t}=3.171$ and $\mathrm{t}$ table $(1-0.05)(44-1)=1.67$ (at $\alpha=$ $0.05)$. Because $t=3.171>$ table $=1.67$, Ho is rejected, meaning a significant path coefficient. Thus Nutrition Status (X1) has a direct and significant influence on learning motivation (X3). Direct Effect of Physical Fitness (X2) on the results of learning motivation (X3). Individual tests conducted $\mathrm{X} 2$ to $\mathrm{X} 3$ obtained from the value of the pyx32 path coefficient $=0.436$ with $\mathrm{t}=2.806$ and $\mathrm{t}$ table $(1-0.05)(44-1)=1.67$ (at $\alpha=0.05)$. Because $t=2.806>$ table $=1.67$, Ho is rejected, meaning a significant path coefficient. Thus Physical Fitness (X2) has a direct and significant influence on learning motivation (X3).

\section{CONCLUSION}

Based on the results of data analysis and discussion described in the previous chapters, it can be concluded (1) There is a direct influence on nutritional status. Learning Outcomes in Grade $\mathrm{X}$ of SMA 1 Padang Pertiwi $2017 / 2018$ academic year by $9.3 \%$, (2) There is a direct influence on the level of fitnessLearning Outcomes in class X of SMA 1 Padang Pertiwi 2017/2018 academic year by $14 \%$, (3) There is a direct influence on learning direct and significant impact on PJOK learning ou motivationLearning Outcomes in Grade $\mathrm{X}$ of SMA 1 Padang Pertiwi 2017/2018 academic year by $8.7 \%$, (4) There is a direct influence on nutritional statusmotivation in class X SMA 1 Padang Pertiwi 2017/2018 academic year by $24 \%$, (5) There is a direct influence on the level of physical fitnessmotivation in class X SMA 1 Padang Pertiwi in the academic year 2017/2018 18.5\%

\section{REFERENCES}

[1] Dalyono. "Psikologi Pendidikan". Jakarta: Rineka Dicadangkan. 2007, pp 47-54.

[2] Hadi H. "Beban ganda masalah dan implikasinya terhadap kebijakan pembangunan kesehatan nasional". Tugas Akhir Gizi. Universitas Surakarta. 2005, pp 25-57.

[3] Karyadi D. "Kecukupan gizi yang dianjurkan". Jakarta: Gramedia Pustaka Utama. 1996. pp 8890.

[4] Peraturan Menteri Pendidikan dan Kebudayan RI No. 23 tahun 2016 tentang Standar Penilaian Pendidikan. Jakarta: Kementerian Pendidikan dan Kebudayaan. 2016, pp 54-66

[5] Sugiyono. "Metode Penelitian Pendidikan Metode Kuantitatif, Kualitatif, dan R\&D. Bandung: Alfabeta. 2014, pp 85-98. 